\title{
The farnesoid $X$ receptor and colon cancer
}

\author{
Guofeng Xie, Jean-Pierre Raufman \\ Division of Gastroenterology and Hepatology, Veterans Affairs Maryland Health Care System, University of Maryland School of Medicine, \\ Baltimore, MD 21201, USA.
}

Correspondence to: Dr. Guofeng Xie, Division of Gastroenterology and Hepatology, Veterans Affairs Maryland Health Care System, University of Maryland School of Medicine, 22 South Greene Street, Baltimore, MD 21201, USA. E-mail: gxie@medicine.umaryland.edu

\section{A B S T R A C T}

Worldwide, colorectal cancer (CRC) is a leading cause of cancer death, primarily because of limited therapeutic options for those with advanced disease. The farnesoid X receptor (FXR) is a member of the nuclear receptor superfamily of ligand-activated transcription factors. Besides its prominent role in bile acid synthesis, and lipoprotein and glucose metabolism, recent data indicate that FXR also plays a key role in regulating intestinal cell proliferation and carcinogenesis. Here, we review the role of FXR as a tumor suppressor in CRC, with particular emphasis on the molecular mechanisms underlying FXR-dependent tumorigenesis and its regulation, FXR-bile acid relationships and FXR-targeted drugs as potential therapeutic agents.

Key words: Colon cancer; farnesoid X receptor; nuclear receptor; tumor suppressor

\section{INTRODUCTION}

Despite advances in screening and treatment, colorectal cancer (CRC) results in over 50,000 deaths yearly and may soon surpass lung cancer as the overall leading cause of cancer-related death in the USA alone. ${ }^{[1,2]}$ Despite increased efforts to improve access and compliance, many people neglect CRC screening. In addition, the efficacy of colon cancer screening is limited by the limited sensitivity of tests, "miss" rates on colonoscopy and other factors. Chemoprevention using non-steroidal anti-inflammatory drugs is marginally effective ${ }^{[3,4]}$ but limited by gastrointestinal $(\mathrm{GI})^{[5]}$ and cardiovascular ${ }^{[6]}$ toxicity that led to the withdrawal of rofecoxib. ${ }^{[7]}$ Nonsurgical treatments (e.g. chemotherapy and radiation) for advanced colon cancer have limited efficacy. Although the use of biologicals that target vascular endothelial growth factor and epidermal growth factor receptor (EGFR) (i.e. bevacizumab, cetuximab and panitumumab) may increase survival with advanced CRC by several months, these agents have a limited impact on 5-year survival, on the order of only $10 \%{ }^{[8-10]}$ Moreover, their use is limited by off-target toxicity that commonly reduces patient tolerance; EGFR, which is expressed widely in non-intestinal epithelial cells (e.g. dermal epithelial cells), ${ }^{[11]}$ causes skin reactions that may force

\begin{tabular}{|l|l|}
\hline \multicolumn{3}{|c|}{ Access this article online } \\
\hline Quick Response Code: & Website: \\
& www.jcmtjournal.com \\
\cline { 2 - 2 } & \\
\hline
\end{tabular}

discontinuation of treatment.

\section{FARNESOID X RECEPTORAND ITS LIGANDS}

Farnesoid X receptor (FXR) [nuclear receptor subfamily 1, group $\mathrm{H}$, member $4(\mathrm{NR} 1 \mathrm{H} 4)$ ] is a member of the nuclear receptor superfamily of ligand-activated transcription factors and acts as a bile acid sensor. ${ }^{[12-14]}$ FXR regulates the expression of genes involved in bile acid synthesis, and cholesterol and triglyceride metabolism by binding to their promoters as a homo- or hetero-dimer with a common partner of nuclear receptors, retinoid X receptor. FXR agonists include naturally-occurring bile acids (e.g. chenodeoxycholic acid [CDCA; EC50 of $10-50 \mu \mathrm{mol} / \mathrm{L}]),{ }^{[15]}$ synthetic compounds GW4064 (EC50 of $15 \mathrm{nmol} / \mathrm{L}){ }^{[16]}$ 6E-CDCA (EC50 of $99 \mathrm{nmol} / \mathrm{L}$ ), ${ }^{[17]}$ WAY-362450 (EC50 of $\left.4 \mathrm{nmol} / \mathrm{L}\right)^{[18]}$ and fexaramine (EC50 of $25 \mathrm{nmol} / \mathrm{L}) ;{ }^{[19]} \mathrm{FXR}$ antagonists include plant-derived guggulsterone ${ }^{[20]}$ and synthetic AGN34. ${ }^{[21]}$ The FXR agonist fexaramine is poorly absorbed following oral administration; thus, it acts as an intestine-restricted FXR agonist without systemic side-effects. ${ }^{[19]}$ Oral administration of fexaramine results in serum levels that are an order of magnitude lower than those obtained following intraperitoneal injection of the drug, and it activates FXR target genes only in the GI tract. ${ }^{[19]}$

This is an open access article distributed under the terms of the Creative Commons Attribution-NonCommercial-ShareAlike 3.0 License, which allows others to remix, tweak, and build upon the work non-commercially, as long as the author is credited and the new creations are licensed under the identical terms.

For reprints contact: service@oaepublish.com

How to cite this article: Xie G, Raufman JP. The farnesoid X recepto and colon cancer. J Cancer Metastasis Treat 2016;2:24-8.

Received: 29-04-2015; Accepted: 21-07-2015 


\section{FXR EXPRESSION AND REGULATION IN NORMAL INTESTINAL MUCOSA}

FXR is expressed primarily in the GI tract, liver and kidney. ${ }^{[22,23]}$ Modica et al. ${ }^{[24]}$ showed that murine FXR (Nr1h4) is expressed at high levels in the small intestine and colon, whereas human FXR (NR1H4) is expressed at moderate levels in the colon. FXR expression is localized primarily to fully differentiated cells lining the intestinal epithelium of the ileum and colon. ${ }^{[24]}$ In the $A p c^{\mathrm{min} /+}$ murine model of CRC, FXR messenger RNA (mRNA) levels were down-regulated in tumor tissue compared with adjacent normal mucosa. Likewise, in patients with familial adenomatous polyposis (FAP) syndrome, FXR mRNA expression was decreased in normal and neoplastic tissues. In a human CRC cell line, HT-29 cells, restoring wild-type APC protein induced FXR expression, suggesting that APC may directly or indirectly regulate FXR expression. ${ }^{[24]}$ FXR can also be regulated at the transcriptional level by the caudal-related homeobox 2. ${ }^{[25]}$ Moreover, Bailey et $a l .{ }^{[26]}$ showed that DNA methylation and KRAS signaling silence FXR in human CRC. In approximately, 12\% of human colon cancers and in several colon cancer cell lines, including SW620, FXR promoter methylation of a $\mathrm{CpG}$ island results in very low FXR expression. ${ }^{[26]}$ Cabrerizo et $a{ }^{[27]}$ found FXR promoter methylation at two additional CpG islands (-358 and $-1890 \mathrm{bp})$. Furthermore, functional analysis of the 5 '-promoter region of the human FXR gene in HepG2 cells suggests that hepatic nuclear factor 1a may be a transcription factor for FXR. ${ }^{[28]}$

\section{FXR ISAN INTESTINALTUMOR SUPPRESSOR}

In addition to its essential role in regulating lipid metabolism, emerging evidence supports a key role for FXR as an intestinal tumor suppressor. In two mouse models of $\mathrm{CRC}$, $A p c^{\text {min/+ }}$ and chronic colitis, Modica et al. ${ }^{[29]}$ showed that FXR deficiency increased adenoma size and number. In a xenograft model, they showed that FXR reactivation via adenoviral infection blocked tumor growth. Using $A p c^{\text {min/+ }}$ and azoxymethane-induced mouse models of CRC, Maran et $a l .{ }^{[30]}$ confirmed that FXR was an intestinal tumor suppressor. Smith et al. ${ }^{[31]}$ showed that activating FXR with sodium taurocholate markedly reduced adenoma formation in $\mathrm{Apc}^{\mathrm{min} /+}$ mice.

FXR is down-regulated drastically in colon tumors from both murine $\left(A p c^{\mathrm{min} /+}\right)$ and human FAP models of CRC..$^{[24]}$ FXR mRNA expression is reduced in colon adenomas and even more profoundly in colon adenocarcinomas. ${ }^{[32,33]}$ Diminished FXR expression is associated with advanced CRC stage and an adverse prognosis. ${ }^{[26,33]}$

Colon cancer risk increases substantially with chronic intestinal inflammation as in inflammatory bowel disease, including both Crohn's and ulcerative colitis (UC) ${ }^{[34,35]}$ FXR activation decreases the production of pro-inflammatory cytokines, such as interleukin (IL) 1-beta, IL-2, IL-6, tumor necrosis factor-alpha and interferon-gamma, thereby reducing inflammation and intestinal permeability. ${ }^{[36]}$ Torres et al. ${ }^{[37]}$ showed that FXR expression was inversely correlated with neoplastic progression and the severity of colonic inflammation in UC. FXR expression is also reduced in colonic mucosa from patients with primary sclerosing cholangitis (PSC) and UC-associated neoplasia. Compared to patients with UC alone, those with PSC-UC have diminished FXR expression in the right colon suggesting they are at a higher risk of proximal colon neoplasia. ${ }^{[37]}$

\section{FXR AND COLON CARCINOGENESIS}

Although the above observations strongly implicate FXR as a tumor suppressor, the underlying mechanism is incompletely understood. No mutations have been identified in the FXR gene in CRC. ${ }^{[26]}$ Several studies suggest the role of FXR in colon carcinogenesis is multifactorial. Modica et al. ${ }^{[29]}$ showed the importance of Wnt signaling and apoptosis downstream of FXR. FXR promotes Wnt signaling with the expansion of basal proliferative intestinal cells, and a concomitant reduction in the apoptosis-competent apical epithelium. When FXR is activated in CRC cells, induction of apoptosis results in the removal of genetically altered tumor cells. The same investigators showed that FXR activation increased expression of several pro-apoptotic genes, including FAS, BAK1, P21, KLF4, FADD, CAS9 and P27. Maran et al. ${ }^{[30]}$ showed that FXR deficiency increases intestinal cell proliferation, accompanied by up-regulation of cyclin D1 and IL-6. In addition, it was shown that sodium taurocholate inhibits intestinal tumorigenesis by activating FXR, leading to increased Shp expression and consequent down-regulation of cyclin D1. ${ }^{[31]}$

Several other potential mechanisms may account for FXR inhibition of intestinal tumor genesis. Peng et al. ${ }^{[38]}$ showed that Src-mediated cross-talk between FXR and the EGFR inhibited human intestinal cell proliferation in vitro and growth of human colon cancer xenografts in nude mice. Yang et al. ${ }^{[39]}$ has showed that FXR is a transcription factor for microRNA-22, and also a tumor suppressor which silences cyclin A gene expression in colon cancer cells. In inflammation-associated intestinal neoplasia, activation of FXR is repressed by pro-inflammatory cytokines that activate intestinal nuclear factor-kB signaling; ${ }^{[40]}$ the investigators concluded that FXR not only inhibits inflammation, but also is targeted by the inflammatory response, resulting in a vicious cycle where reduced FXR activity causes less repression of inflammation. Zhou et al. ${ }^{[41]}$ also showed that activation of the PPAR $\alpha$-UGT axis repressed intestinal FXR-FGF15/19 feed-back and exacerbates experimental colitis, thereby possibly promoting intestinal tumorigenesis. In mice, both PPAR $\alpha$ knockout and treatment with recombinant FGF19 strongly attenuated dextran sulfate sodium-induced colitis. ${ }^{[41]}$ 


\section{ROLE OF BILE ACIDS IN FXR-MEDIATED INHIBITION OF TUMORIGENESIS}

Colon cancer is often linked to a Western diet, rich in carbohydrates and saturated fatty acids. ${ }^{[42-44]}$ Subjects who consume a Western diet and patients with CRC have elevated levels of fecal secondary bile acids, mostly lithocholic acid (LCA) and deoxycholic acid (DCA), implicating bile acids as contributing factors in colon carcinogenesis. ${ }^{[45-48]}$ Although controversial, cholecystectomy, which increases intestinal bile acid levels, may predispose persons to CRC. ${ }^{[49,50]}$ Nonetheless, recent evidence suggests that FXR inhibits intestinal tumorigenesis through a bile acid-independent mechanism. Degirolamo et al..$^{[51]}$ showed that FXR deficiency, not elevated bile acid levels, mediated susceptibility to intestinal tumorigenesis. The tumor-promoting activity of bile acids does not occur as a function of their ability to activate FXR in the intestines. ${ }^{[29,51]}$ Raufman et al. showed that several bile acids, including DCA and LCA, promoted colon carcinogenesis and cell proliferation by interacting with M3 muscarinic receptors that are overexpressed in a majority of colon cancers and human colon cancer cells through transactivation of EGFR. ${ }^{[52-55]}$ Although the role of FXR as an intestinal tumor suppressor might not be directly mediated by bile acids, FXR activation can have tumor-suppressive effects by transcriptional induction of detoxifying enzymes that mediate transformation and excretion of toxic bile acids. ${ }^{[51]}$ Interestingly, FXR's role in liver cancer (hepatocellular carcinoma) as a tumor suppressor may be mediated by bile acids. ${ }^{[56-59]}$

\section{FUTURE DIRECTIONS}

In addition to being a master regulator of bile acid synthesis, and glucose and fat metabolism, recent research data reveal a novel and important role for FXR as a tumor suppressor in intestinal carcinogenesis, cell proliferation and tumor growth. Because FXR is considerably downregulated in colon tumor cells, restoring or reactivating FXR expression may offer a therapeutic strategy. In addition, because normal intestinal epithelial cells express high levels of FXR, pharmacological FXR agonists might be effective chemopreventive agents, particularly in high-risk populations, including those with hereditary CRC (e.g. FAP and Lynch syndrome). To avoid systemic toxicity associated with FXR activation (e.g. 6E-CDCA can cause pruritus ${ }^{[60]}$ intestine-specific FXR agonists, like fexaramine may be especially useful. ${ }^{[19]}$

\section{Acknowledgments}

This work was supported by the office of Research and Development, Medical Research Service, Department of Veterans Affairs and NIH T32 DK067872 (J. P. Raufman) and by American Cancer Society Institutional Research Grant (G. Xie).
Financial support and sponsorship Nil.

\section{Conflicts of interest}

There are no conflicts of interest.

\section{REFERENCES}

1. Howlader N, Noone A, Krapcho M, Neyman N, Aminou R, Waldron W, Altekruse S, Kosary C, Ruhl J, Tatalovich Z, Cho H, Mariotto A, Eisner M, Lewis D, Chen H, Feuer E, Cronin K, Edwards B. SEER Cancer Statistics Review, 1975-2008, Bethesda, MD: national Cancer Institute. Based on November 2010 SEER Data Submission, Posted to the SEER; 2011. Available from: http://www. seer.cancer.gov/csr/1975-2008/. [Last accessed on 2015 Jul 20].

2. Peery AF, Dellon ES, Lund J, Crockett SD, McGowan CE, Bulsiewicz WJ, Gangarosa LM, Thiny MT, Stizenberg K, Morgan DR, Ringel Y, Kim HP, Dibonaventura MD, Carroll CF, Allen JK, Cook SF, Sandler RS, Kappelman MD, Shaheen NJ. Burden of gastrointestinal disease in the United States: 2012 update. Gastroenterology 2012;143:1179-87e1-3.

3. Baron JA, Sandler RS, Bresalier RS, Quan H, Riddell R, Lanas A, Bolognese JA, Oxenius B, Horgan K, Loftus S, Morton DG. A randomized trial of rofecoxib for the chemoprevention of colorectal adenomas. Gastroenterology 2006;131:1674-82.

4. Bertagnolli MM, Eagle CJ, Zauber AG, Redston M, Solomon SD, Kim K, Tang J, Rosenstein RB, Wittes J, Corle D, Hess TM, Woloj GM, Boisserie F, Anderson WF, Viner JL, Bagheri D, Burn J, Chung DC, Dewar T, Foley TR, Hoffman N, Macrae F, Pruitt RE, Saltzman JR, Salzberg B, Sylwestrowicz T, Gordon GB, Hawk ET. Celecoxib for the prevention of sporadic colorectal adenomas. N Engl J Med 2006;355:873-84.

5. Helin-Salmivaara A, Saarelainen S, Gronroos JM, Vesalainen R, Klaukka T, Huupponen R. Risk of upper gastrointestinal events with the use of various NSAIDs: a case-control study in a general population. Scand J Gastroenterol 2007;42:923-32.

6. Kerr DJ, Dunn JA, Langman MJ, Smith JL, Midgley RS, Stanley A, Stokes JC, Julier P, Iveson C, Duvvuri R, McConkey CC. Rofecoxib and cardiovascular adverse events in adjuvant treatment of colorectal cancer. N Engl J Med 2007;357:360-9.

7. McGettigan P, Henry D. Cardiovascular risk and inhibition of cyclooxygenase: a systematic review of the observational studies of selective and nonselective inhibitors of cyclooxygenase 2 . JAMA 2006;296:1633-44.

8. Modjtahedi H, Essapen S. Epidermal growth factor receptor inhibitors in cancer treatment: advances, challenges and opportunities. Anticancer Drugs 2009;20:851-5.

9. Overman MJ, Hoff PM. EGFR-targeted therapies in colorectal cancer. Dis Colon Rectum 2007;50:1259-70.

10. Venook AP. Epidermal growth factor receptor-targeted treatment for advanced colorectal carcinoma. Cancer 2005;103:2435-46.

11. Sipples R. Common side effects of anti-EGFR therapy: acneform rash. Semin Oncol Nurs 2006;22:28-34.

12. Gadaleta RM, van Mil SW, Oldenburg B, Siersema PD, Klomp LW, van Erpecum KJ. Bile acids and their nuclear receptor FXR: relevance for hepatobiliary and gastrointestinal disease. Biochim Biophys Acta 2010;1801:683-92.

13. Lee FY, Lee H, Hubbert ML, Edwards PA, Zhang Y. FXR, a multipurpose nuclear receptor. Trends Biochem Sci 2006;31:572-80.

14. Wang YD, Chen WD, Moore DD, Huang W. FXR: a metabolic regulator and cell protector. Cell Res 2008;18:1087-95.

15. Parks DJ, Blanchard SG, Bledsoe RK, Chandra G, Consler TG, Kliewer SA, Stimmel JB, Willson TM, Zavacki AM, Moore DD, Lehmann JM. Bile acids: natural ligands for an orphan nuclear 
receptor. Science 1999;284:1365-8.

16. Maloney PR, Parks DJ, Haffner CD, Fivush AM, Chandra G, Plunket KD, Creech KL, Moore LB, Wilson JG, Lewis MC, Jones SA, Willson TM. Identification of a chemical tool for the orphan nuclear receptor FXR. J Med Chem 2000;43:2971-4.

17. Pellicciari R, Fiorucci S, Camaioni E, Clerici C, Costantino G, Maloney PR, Morelli A, Parks DJ, Willson TM. 6alpha-ethylchenodeoxycholic acid (6-ECDCA), a potent and selective FXR agonist endowed with anticholestatic activity. $J$ Med Chem 2002;45:3569-72.

18. Flatt B, Martin R, Wang TL, Mahaney P, Murphy B, Gu XH, Foster P, Li J, Pircher P, Petrowski M, Schulman I, Westin S, Wrobel J, Yan G, Bischoff E, Daige C, Mohan R. Discovery of XL335 (WAY362450), a highly potent, selective, and orally active agonist of the farnesoid X receptor (FXR). J Med Chem 2009;52:904-7.

19. Fang S, Suh JM, Reilly SM, Yu E, Osborn O, Lackey D, Yoshihara E, Perino A, Jacinto S, Lukasheva Y, Atkins AR, Khvat A, Schnabl B, Yu RT, Brenner DA, Coulter S, Liddle C, Schoonjans K, Olefsky JM, Saltiel AR, Downes M, Evans RM. Intestinal FXR agonism promotes adipose tissue browning and reduces obesity and insulin resistance. Nat Med 2015;21:159-65.

20. Urizar NL, Liverman AB, Dodds DT, Silva FV, Ordentlich P, Yan Y, Gonzalez FJ, Heyman RA, Mangelsdorf DJ, Moore DD. A natural product that lowers cholesterol as an antagonist ligand for FXR. Science 2002;296:1703-6.

21. Dussault I, Beard R, Lin M, Hollister K, Chen J, Xiao JH, Chandraratna R, Forman BM. Identification of gene-selective modulators of the bile acid receptor FXR. $J$ Biol Chem 2003;278:7027-33.

22. Bookout AL, Jeong Y, Downes M, Yu RT, Evans RM, Mangelsdorf DJ. Anatomical profiling of nuclear receptor expression reveals a hierarchical transcriptional network. Cell 2006;126:789-99.

23. Yang X, Downes M, Yu RT, Bookout AL, He W, Straume M, Mangelsdorf DJ, Evans RM. Nuclear receptor expression links the circadian clock to metabolism. Cell 2006;126:801-10.

24. Modica S, Gofflot F, Murzilli S, D’Orazio A, Salvatore L, Pellegrini F, Nicolucci A, Tognoni G, Copetti M, Valanzano R, Veschi S, Mariani-Costantini R, Palasciano G, Schoonjans K, Auwerx J, Moschetta A. The intestinal nuclear receptor signature with epithelial localization patterns and expression modulation in tumors. Gastroenterology 2010;138:636-48, 48e1-12.

25. Modica S, Cariello M, Morgano A, Gross I, Vegliante MC, Murzilli S, Salvatore L, Freund JN, Sabba C, Moschetta A. Transcriptional regulation of the intestinal nuclear bile acid farnesoid $\mathrm{X}$ receptor (FXR) by the caudal-related homeobox 2 (CDX2). J Biol Chem 2014;289:28421-32.

26. Bailey AM, Zhan L, Maru D, Shureiqi I, Pickering CR, Kiriakova G, Izzo J, He N, Wei C, Baladandayuthapani V, Liang H, Kopetz S, Powis G, Guo GL. FXR silencing in human colon cancer by DNA methylation and KRAS signaling. Am J Physiol Gastrointest Liver Physiol 2014;306:G48-58.

27. Cabrerizo R, Castano GO, Burgueno AL, Fernandez Gianotti T, Gonzalez Lopez Ledesma MM, Flichman D, Pirola CJ, Sookoian S. Promoter DNA methylation of farnesoid X receptor and pregnane $\mathrm{X}$ receptor modulates the intrahepatic cholestasis of pregnancy phenotype. PLoS One 2014;9:e87697.

28. Lou G, Li Y, Chen B, Chen M, Chen J, Liao R, Zhang Y, Wang Y, Zhou D. Functional analysis on the 5'-flanking region of human FXR gene in HepG2 cells. Gene 2007;396:358-68.

29. Modica S, Murzilli S, Salvatore L, Schmidt DR, Moschetta A. Nuclear bile acid receptor FXR protects against intestinal tumorigenesis. Cancer Res 2008;68:9589-94.

30. Maran RR, Thomas A, Roth M, Sheng Z, Esterly N, Pinson D, Gao X, Zhang Y, Ganapathy V, Gonzalez FJ, Guo GL. Farnesoid X receptor deficiency in mice leads to increased intestinal epithelial cell proliferation and tumor development. $J$ Pharmacol Exp Ther 2009;328:469-77.

31. Smith DL, Keshavan P, Avissar U, Ahmed K, Zucker SD. Sodium taurocholate inhibits intestinal adenoma formation in APCMin/+ mice, potentially through activation of the farnesoid $\mathrm{X}$ receptor. Carcinogenesis 2010;31:1100-9.

32. De Gottardi A, Touri F, Maurer CA, Perez A, Maurhofer O, Ventre G, Bentzen CL, Niesor EJ, Dufour JF. The bile acid nuclear receptor FXR and the bile acid binding protein IBABP are differently expressed in colon cancer. Dig Dis Sci 2004;49:982-9.

33. Lax S, Schauer G, Prein K, Kapitan M, Silbert D, Berghold A, Berger A, Trauner M. Expression of the nuclear bile acid receptor/farnesoid $\mathrm{X}$ receptor is reduced in human colon carcinoma compared to nonneoplastic mucosa independent from site and may be associated with adverse prognosis. Int $J$ Cancer 2012;130:2232-9.

34. Ullman TA, Itzkowitz SH. Intestinal inflammation and cancer. Gastroenterology 2011;140:1807-16.

35. Gadaleta RM, Cariello M, Sabba C, Moschetta A. Tissue-specific actions of FXR in metabolism and cancer. Biochim Biophys Acta 2015;1851:30-9.

36. Stojancevic M, Stankov K, Mikov M. The impact of farnesoid X receptor activation on intestinal permeability in inflammatory bowel disease. Can J Gastroenterol 2012;26:631-7.

37. Torres J, Bao X, Iuga AC, Chen A, Harpaz N, Ullman T, Cohen BL, Pineton de Chambrun G, Asciutti S, Odin JA, Sachar DB, Gaskins HR, Setchell K, Colombel JF, Itzkowitz SH. Farnesoid X receptor expression is decreased in colonic mucosa of patients with primary sclerosing cholangitis and colitis-associated neoplasia. Inflamm Bowel Dis 2013;19:275-82.

38. Peng Z, Raufman JP, Xie G. Src-mediated cross-talk between farnesoid $\mathrm{X}$ and epidermal growth factor receptors inhibits human intestinal cell proliferation and tumorigenesis. PLoS One 2012;7:e48461.

39. Yang $\mathrm{F}, \mathrm{Hu} \mathrm{Y}$, Liu HX, Wan YJ. miR-22-silenced cyclin A expression in colon and liver cancer cells is regulated by bile acid receptor. J Biol Chem 2015;290:6507-15.

40. Gadaleta RM, Oldenburg B, Willemsen EC, Spit M, Murzilli S, Salvatore L, Klomp LW, Siersema PD, van Erpecum KJ, van Mil SW. Activation of bile salt nuclear receptor FXR is repressed by pro-inflammatory cytokines activating NF-kappaB signaling in the intestine. Biochim Biophys Acta 2011;1812:851-8.

41. Zhou X, Cao L, Jiang C, Xie Y, Cheng X, Krausz KW, Qi Y, Sun L, Shah YM, Gonzalez FJ, Wang G, Hao H. PPARalpha-UGT axis activation represses intestinal FXR-FGF15 feedback signalling and exacerbates experimental colitis. Nat Commun 2014;5:4573.

42. Berg A. Nutrition, development, and population growth. Popul Bull 1973;29:3-37.

43. Chao A, Thun MJ, Connell CJ, McCullough ML, Jacobs EJ, Flanders WD, Rodriguez C, Sinha R, Calle EE. Meat consumption and risk of colorectal cancer. JAMA 2005;293:172-82.

44. Kirkegaard H, Johnsen NF, Christensen J, Frederiksen K, Overvad K, Tjonneland A. Association of adherence to lifestyle recommendations and risk of colorectal cancer: a prospective Danish cohort study. BMJ 2010;341:c5504.

45. Bajor A, Gillberg PG, Abrahamsson H. Bile acids: short and long term effects in the intestine. Scand J Gastroenterol 2010;45:645-64.

46. McGarr SE, Ridlon JM, Hylemon PB. Diet, anaerobic bacterial metabolism, and colon cancer: a review of the literature. $J$ Clin Gastroenterol 2005;39:98-109.

47. Bianchini F, Caderni G, Dolara P, Fantetti L, Kriebel D. Effect of dietary fat, starch and cellulose on fecal bile acids in mice. J Nutr 1989;119:1617-24.

48. Reddy BS, Hedges AR, Laakso K, Wynder EL. Metabolic epidemiology of large bowel cancer: fecal bulk and constituents of high-risk North American and low-risk Finnish population. Cancer 
1978;42:2832-8.

49. Giovannucci E, Colditz GA, Stampfer MJ. A meta-analysis of cholecystectomy and risk of colorectal cancer. Gastroenterology 1993;105:130-41.

50. Lagergren J, Ye W, Ekbom A. Intestinal cancer after cholecystectomy: is bile involved in carcinogenesis? Gastroenterology 2001;121:542-7.

51. Degirolamo C, Modica S, Palasciano G, Moschetta A. Bile acids and colon cancer: solving the puzzle with nuclear receptors. Trends Mol Med 2011;17:564-72.

52. Cheng K, Chen Y, Zimniak P, Raufman JP, Xiao Y, Frucht H. Functional interaction of lithocholic acid conjugates with M3 muscarinic receptors on a human colon cancer cell line. Biochim Biophys Acta 2002;1588:48-55.

53. Cheng K, Raufman JP. Bile acid-induced proliferation of a human colon cancer cell line is mediated by transactivation of epidermal growth factor receptors. Biochem Pharmacol 2005;70:1035-47.

54. Raufman JP, Cheng K, Zimniak P. Activation of muscarinic receptor signaling by bile acids: physiological and medical implications. Dig Dis Sci 2003;48:1431-44.

55. Cheng K, Zimniak P, Raufman JP. Transactivation of the epidermal growth factor receptor mediates cholinergic agonist-induced proliferation of H508 human colon cancer cells. Cancer Res 2003;63:6744-50.

56. Degirolamo C, Modica S, Vacca M, Di Tullio G, Morgano A, D'Orazio A, Kannisto K, Parini P, Moschetta A. Prevention of spontaneous hepatocarcinogenesis in farnesoid $\mathrm{X}$ receptor-null mice by intestinal-specific farnesoid $\mathrm{X}$ receptor reactivation. Hepatology 2015;61:161-70.

57. Iannelli F, Collino A, Sinha S, Radaelli E, Nicoli P, D’Antiga L, Sonzogni A, Faivre J, Buendia MA, Sturm E, Thompson RJ, Knisely AS, Natoli G, Ghisletti S, Ciccarelli FD. Massive gene amplification drives paediatric hepatocellular carcinoma caused by bile salt export pump deficiency. Nat Commun 2014;5:3850.

58. Yang F, Huang X, Yi T, Yen Y, Moore DD, Huang W. Spontaneous development of liver tumors in the absence of the bile acid receptor farnesoid X receptor. Cancer Res 2007;67:863-7.

59. Schaap FG, Jansen PL, Olde Damink SW. FXR, intestinal FiXeR of hepatocellular carcinoma? Hepatology 2015;61:21-3.

60. Ma Y, Huang Y, Yan L, Gao M, Liu D. Synthetic FXR agonist GW4064 prevents diet-induced hepatic steatosis and insulin resistance. Pharm Res 2013;30:1447-57. 